\title{
Greenhouse and Field Evaluation of Biological Control of Fusarium Head Blight on Durum Wheat
}

\author{
D. A. Schisler, Research Plant Pathologist, United States Department of Agriculture-Agricultural Research Service \\ (USDA-ARS), National Center for Agricultural Utilization Research (NCAUR); N. I. Khan, Postdoctoral Plant \\ Pathologist, Department of Plant Pathology, Ohio State University; M. J. Boehm, Associate Professor of Plant Pa- \\ thology, Department of Plant Pathology, Ohio State University, Columbus 43210; and P. J. Slininger, Supervisory \\ Chemical Engineer, USDA-ARS, NCAUR, Peoria, IL 61604
}

\begin{abstract}
Schisler, D. A., Khan, N. I., Boehm, M. J., and Slininger, P. J. 2002. Greenhouse and field evaluation of biological control of Fusarium head blight on durum wheat. Plant Dis. 86:13501356.

Fusarium head blight (FHB) is a devastating disease that causes extensive yield and quality losses to wheat and barley. In durum wheat, the pathogen-produced toxin deoxynivalenol (DON) is retained in semolina at $\sim 50 \%$, and the causal agent of FHB, Gibberella zeae, has a strong adverse effect on pasta color. Two bacteria and two yeast strains with known efficacy against G. zeae on hexaploid wheats were produced in liquid culture and assayed on two cultivars of durum wheat in greenhouse bioassays. All antagonists reduced FHB severity on cultivar Renville, and three of the four reduced severity on cultivar Ben, with Bacillus subtilis strain AS 43.3 decreasing FHB severity by as much as $90 \%$. In separate greenhouse bioassays, the carbon:nitrogen ratio of the medium used to produce antagonists did not consistently influence antagonist efficacy. All antagonist/production medium combinations but one were effective in reducing disease on both durum cultivars. Of six antagonists tested at field sites, Cryptococcus sp. $\mathrm{OH} 71.4$ and C. nodaensis $\mathrm{OH} 182.9$ reduced disease severity by as much as $57 \%$ in Peoria, IL, while Cryptococcus sp. OH 181.1 reduced disease severity by as much as $59 \%$ in a trial at Langdon, ND. Antagonists did not influence the DON content of grain in the Peoria trial. Relative performance indices for four antagonists calculated from greenhouse and field results on the two durum cultivars demonstrated that the bioassay location, but not the cultivar of durum, influenced the relative performance of antagonists. Yeast antagonists $\mathrm{OH} 71.4, \mathrm{OH} 181.1$, and $\mathrm{OH} 182.9$ appear to have the highest potential for contributing to the reduction of FHB on durum wheat in the field.
\end{abstract}

Additional keywords: Fusarium graminearum, scab of wheat

Durum wheat (Triticum durum Desf.) is a tetraploid wheat that ranks approximately eighth in worldwide cereal production. It is used primarily in the production of pasta in North America and Europe but also in couscous in the Middle East and North Africa (3). Fusarium head blight (FHB) is an important disease of wheat and barley in humid and semihumid regions of the world (23). It has the potential to completely destroy an otherwise healthy crop only weeks before harvest by infecting developing heads at the time of flowering through the soft dough stage of kernel development. Fusarium head blight in the United States was particularly devastating in the 1990s, with losses to U.S. agriculture esti-

Corresponding author: D. A. Schisler

E-mail: Schislda@ncaur.usda.gov

Accepted for publication 23 July 2002.

Publication no. D-2002-1018-01R

This article is in the public domain and not copyrightable. It may be freely reprinted with customary crediting of the source. The American Phytopathological Society, 2002. mated at over $\$ 2.6$ billion (23). Gibberella zeae (Schwein.) (anamorph Fusarium graminearum Schwabe) is the primary causal agent of FHB, or scab, on durum wheat as well as other wheats and barley in North America (1). The pathogen is genetically diverse on a regional basis $(22,41)$ and maintains reproductively isolated lineages across the globe (25).

In addition to destroying yields, G. zeae can produce mycotoxins such as zearalenone (14) and deoxynivalenol (DON, vomitoxin) $(12,35)$ during colonization of grain. DON is retained in semolina at approximately $50 \%$, and G. zeae has a strong adverse effect on pasta color when $G$. zeae-damaged kernels make up as little as $2 \%$ of a lot (6). Grain that is heavily contaminated by DON is frequently unsuitable for human consumption and may be refused as feed $(9,40)$.

Promising options for controlling Fusarium head blight include chemical measures and the development of resistant cultivars. Registered fungicides can be somewhat effective in reducing FHB $(16,21,38)$, but residue concerns regarding the use of fungicides late in crop develop- ment lessen their attractiveness. Advances in developing resistant cultivars using traditional breeding (2) and genetic engineering (5) are occurring, but all wheat cultivars currently in production remain vulnerable to infection. Although partially effective in reducing FHB, conventional tillage of fields after harvesting to bury plant residues and reduce available pathogen inoculum $(7,24,44)$ is not compatible with the soil conservation practice of minimum tillage.

Biological control of FHB holds considerable promise and includes the treatment of crop residues with antagonists to reduce pathogen inoculum (4) and wheat heads at anthesis to reduce infection $(11,17,26$, $37,42)$. Biological control of FHB is attractive due to its potential for being environmentally benign, compatible with other control measures, and durable.

Khan et al. (17) isolated seven novel microbial strains from wheat anthers and demonstrated their efficacy against isolates of $G$. zeae in greenhouse studies on the hard red spring wheat cultivar Norm. The potential of these strains to control FHB on wheat in a field environment, however, was not described. Further, the ability of these strains to control FHB on durum wheat was not attempted in greenhouse nor in field studies. Frequently, biological control agents shown to be effective in greenhouse bioassays do not perform similarly in field experiments $(15,20)$. Whether this trend would be seen when testing these strains on durum wheat in greenhouse and field trials was not known. The quantity and quality of nutrients present in a liquid culture medium can influence the efficacy of the antagonists produced $(32,33)$. The efficacy of biological control agents can also vary relative to each other and overall when assayed on different host cultivars (32). A primary objective of this study was to test the efficacy of biological control agents against FHB on two durum wheat cultivars in greenhouse and field studies. An additional objective of the greenhouse studies was to determine if the nutritional environment used to produce antagonist biomass differentially influenced antagonist efficacy on durum wheat. Final objectives were to evaluate whether individual antagonist efficacy varied relative to the other strains when antagonists were tested 
in greenhouse and field environments and whether the cultivar of durum used in an experiment also influenced relative antagonist efficacy.

\section{MATERIALS AND METHODS}

Production of antagonist inoculum. Bacillus subtilis AS 43.3, B. subtilis AS 43.4, Cryptococcus sp. $\mathrm{OH} 71.4$, and $C$. nodaensis $\mathrm{OH} 182.9$ were utilized in all studies. B. subtilis $\mathrm{OH} 131.1$ and Cryptococcus sp. nov. $\mathrm{OH} 181.1$ were used in says (Table 1). Strains were stored at $-80^{\circ} \mathrm{C}$ in $10 \%$ glycerol and were streaked for purity on 1/5 Tryptic soy broth agar (TSBA/5, pH 6.8) (Difco Laboratories, Detroit, MI) to produce cells for inoculating liquid media. Cultures were incubated at $25^{\circ} \mathrm{C}$ for $24 \mathrm{~h}$. For greenhouse studies, inoculum was produced in a semidefined complete liquid medium (SDCL; 32) with a carbon:nitrogen $(\mathrm{C}: \mathrm{N})$ ratio of 11.0 and total carbon content of $14.0 \mathrm{~g} /$ liter. Fifty milliliters of SDCL in 200-ml unbaffled Erlenmeyer flasks was inoculated to an optical density (OD) of 0.10 at $620-\mathrm{nm}$ wavelength light $\left(A_{620}\right)$ with cells grown on TSBA $/ 5$ at $25^{\circ} \mathrm{C}$ for $24 \mathrm{~h}$. Flasks were then incubated in a shaker incubator at $250 \mathrm{rpm}$, $2.0-\mathrm{cm}$ eccentricity, and $25^{\circ} \mathrm{C}$ for $48 \mathrm{~h}$ prior to use. An SDCL medium with a C:N of 6.5 and identical total carbon content was also used to produce cells of each antagonist for the study of medium C:N effect on antagonist efficacy. Media of differing $\mathrm{C}: \mathrm{N}$ are obtained by varying the ratio of glucose and Casamino acids while maintaining constant carbon loading. For field studies, cells grown for $24 \mathrm{~h}$ on TSBA/5 plates were used to seed $100 \mathrm{ml}$ SDCL (C:N 6.5) contained in 500-ml flasks to an OD of 0.10 at $A_{620}$. Flasks were incubated at $25^{\circ} \mathrm{C}$ and $250 \mathrm{rpm}(2.5$ $\mathrm{cm}$ eccentricity). After $24 \mathrm{~h}$, these precultures were used to seed Fernbach flasks containing 1.5 liters of SDCL (C:N 6.5) to an OD of 0.10. Cultures were incubated as field trials but not in the greenhouse bioas-

described above for $48 \mathrm{~h}$. Colonized broth were then transferred to sterile containers, transported to the field on ice, and used within $24 \mathrm{~h}$.

Production of pathogen inoculum. For greenhouse studies, conidia of G. zeae isolate Z-3639, originally isolated from wheat in Kansas, were produced on clarified V8 juice agar (CV8 agar) under 12 h/day fluorescent light for 7 days at $24^{\circ} \mathrm{C}$ (31). Suspensions of macroconidia were obtained by flooding the surface of colonized CV8 agar with weak, $\mathrm{pH} 7.2$, phosphate buffer $\left(\mathrm{PO}_{4}\right.$ buffer) $(0.004 \% \mathrm{wt} / \mathrm{vol}$ $\mathrm{KH}_{2} \mathrm{PO}_{4}$ buffer with $0.019 \%$ wt/vol $\mathrm{MgCl}_{2}$; Aid Pack, Gloucester, MA) and dislodging conidia using a sterile inoculating loop.

For field studies conducted in Peoria, IL, G. zeae Z-3639 was grown on yellow dent corn kernels contained in 3- or 4-liter Erlenmeyer flasks. Kernels were soaked in water for $24 \mathrm{~h}$, autoclaved for $60 \mathrm{~min}$ on two consecutive days, and inoculated with $10 \mathrm{ml}$ of a conidial suspension of $G$. zeae Z-3639 containing approximately $2 \times 10^{5}$ $\mathrm{CFU} / \mathrm{ml}$. Upon completion of autoclaving, the swelled corn kernels filled half the volume of a flask. Flasks were kept at room temperature on a laboratory bench for 7 days before use. Naturally occurring inoculum incited disease at the Langdon, ND, field site.

Greenhouse bioassay of antagonists against FHB on two durum cultivars. Studies were conducted in Peoria during fall, winter, and spring months in a climate-controlled greenhouse where temperatures ranged from 15 to $20^{\circ} \mathrm{C}$ at night and 23 to $28^{\circ} \mathrm{C}$ during the day. Highpressure sodium lights supplemented natural sunlight for $14 \mathrm{~h}$ /day during winter months. For durum wheat cultivars Renville and Ben, two seedlings per 19-cmdiameter pot were grown in an air-steam pasteurized $\left(60^{\circ} \mathrm{C}\right.$ for $\left.30 \mathrm{~min}\right)$ potting mix (Terra-lite Redearth mix, W.R. Grace, Cambridge, MA) in a growth chamber

Table 1. Antagonist strain designation and identification of bacteria and yeasts that reduce the severity of Fusarium head blight of wheat

\begin{tabular}{|c|c|c|}
\hline Antagonist & NRRL accession no. ${ }^{\mathrm{a}}$ & Identification \\
\hline AS 43.3 & B-30210 & Bacillus subtilis/amyloliquefaciens \\
\hline AS 43.4 & B-30211 & Bacillus subtilis/amyloliquefaciens \\
\hline OH 71.4 & Y-30213 & Cryptococcus sp. $(=\text { Torula aurea })^{\mathrm{c}}$ \\
\hline OH 131.1 & B-30212 & Bacillus subtilis $^{\mathrm{d}}$ \\
\hline OH 181.1 & Y-30215 & Cryptococcus sp. nov. ${ }^{\mathrm{c}}$ \\
\hline OH 182.9 & Y-30216 & Cryptococcus nodaensis ${ }^{\mathrm{e}}$ \\
\hline
\end{tabular}

a ARS (NRRL) patent culture collection, National Center for Agricultural Utilization Research, Peoria, IL.

b Identification by Deutsche Sammlung von Mikroorganismen und Zelkulturen GmbH (DSMZ), Braunschweig, Germany, based on 16S rDNA sequence homologies and biochemical and physiological tests of taxonomic utility.

${ }^{\mathrm{c}}$ Identification based on nucleotide sequence divergence in domain D1/D2 of large subunit 26S rDNA and on divergence in internal transcribed spacer (ITS) 1/5.8/ITS2 rDNA (C. P. Kurtzman, personal communication).

d Identification by MIDI Labs, Newark, DE, based on 16S rDNA sequence homologies and biochemical and physiological tests of taxonomic utility.

${ }^{\mathrm{e}}$ Identification based on nucleotide sequence divergence in domain D1/D2 of large subunit 26S rDNA and on divergence in ITS 1/5.8/ITS2 rDNA (C. P. Kurtzman, personal communication; 27) $\left(25^{\circ} \mathrm{C}, 14 \mathrm{~h} \mathrm{light} / \mathrm{day}, 600 \mu \mathrm{mol} /\left[\mathrm{m}^{2} / \mathrm{s}\right]\right)$ for approximately 8 weeks prior to use in bioassays. Pots were fertilized after 1 week and weekly thereafter with $50 \mathrm{ml}$ of a solution containing $1.25 \mathrm{~g} /$ liter Peters 20-20-20 (Grace-Sierra Horticultural Products, Milpitas, CA) and $0.079 \mathrm{~g} /$ liter iron chelate (Sprint 330, Becker Underwood, Inc., Ames, IA). Wheat heads were inoculated at anthesis. Microbially colonized broths and conidia of $G$. zeae were suspended together in a solution of $\mathrm{PO}_{4}$ buffer and $0.036 \%$ vol/vol Tween 80 (Sigma Chemical Co., St. Louis, MO). Final concentrations of the inoculum mixture were $5 \times 10^{5}$ conidia per $\mathrm{ml}$ and approximately $5 \times 10^{8}$ $\mathrm{CFU} / \mathrm{ml}$ and $3 \times 10^{7} \mathrm{CFU} / \mathrm{ml}$ for bacteria and yeast strains, respectively, or $25 \%$ of fully colonized, 48-h liquid cultures. Ten microliters of this mixture was used to inoculate a single, centrally located floret on each of 16 wheat heads (four heads per replication; four replications per treatment). Heads inoculated only with a suspension of conidia of $G$. zeae, or a buffer/Tween suspension alone served as controls. Previous greenhouse studies (N. I. Khan, unpublished) indicated that none of the strains of antagonists adversely affected head development in the absence of pathogen inoculum. After inoculation, wheat plants were misted lightly with water and incubated in a plastic humidity chamber at approximately $22^{\circ} \mathrm{C}$ in the greenhouse. After $72 \mathrm{~h}$, plants were transferred from the chamber to greenhouse benches. Plastic humidity chambers consisted of a PVC pipe frame covered with clear plastic. Heads were scored for disease incidence (presence or absence of disease symptoms) and severity using a 0 to $100 \%$ scale (36) 16 days after inoculation. Disease severity values were based on visually assessing the proportion of a head exhibiting premature bleaching that is typical of FHB disease. In this and all other experiments, the association of $G$. zeae with symptomatic tissue was confirmed via plating randomly selected tissue samples on CV8 agar. Heads were then allowed to dry and threshed using a Almaco small vogel plant and head thresher (Nevada, IA) set at the lowest air setting to retain all kernels regardless of their disease status, and 100-kernel weights were determined for each replicate. Treatments were distributed in a completely randomized design. Experiments were conducted two times on each durum cultivar. Data from repeated experiments were pooled after statistical analysis demonstrated that experiment by treatment interactions were seldom significant $(P \leq$ $0.01)$. Disease severity and incidence data were normalized when needed using the arcsine transformation before analysis of variance. Means were separated at $P \leq 0.05$ using Fisher's protected LSD test (PC SAS, version 6.12, SAS Institute, Cary, NC).

Greenhouse bioassay of antagonists produced in liquid media with differing 
carbon:nitrogen ratios. Plant and pathogen inoculum production were as described earlier. Inoculum of the four antagonists was produced using SDCL media with $\mathrm{C}: \mathrm{N}$ ratios of either 11.0 or 6.5 as described earlier. At the onset of flowering, a spray inoculation method was used to mimic the arrival of inoculum at the infection court in the field. Two milliliters of an aqueous suspension containing $5 \times 10^{5}$ conidia per $\mathrm{ml}$ of $G$. zeae isolate $\mathrm{Z} 3639$ and $0.036 \%$ North American Professional Products, Woodstock, IL) over four wheat heads immediately after treating heads with $5 \mathrm{ml}$ of an aqueous suspension containing $0.036 \%$ Tween 80 and antagonist cells. Antagonist cells were applied at $25 \%$ of 48-h colonized broth (approximately $3 \times$ $10^{7}$ and $5 \times 10^{8} \mathrm{CFU} / \mathrm{ml}$ for yeast and bacterial antagonists, respectively). Heads sprayed only with conidia of $G$. zeae served as controls. The experiment was conducted twice on both Renville and Ben cultivars. Treatment replication, disease evaluation, and threshing, were as described earlier. Statistical treatment of data was as described earlier except that, for each cultivar, data were also analyzed as a $2 \times 4$ factorial after removal of controls from the data sets.

Peoria field trial of antagonists against FHB on two durum cultivars. The field site soil was an Orthents complex, with a silty loam surface layer of approximately $25 \mathrm{~cm}$ and an underlying silty clay loam. The site was conventionally cultivated in the fall prior to spring planting of durum wheat cultivars Renville and Ben. Prior to planting, the site was fertilized with $1,120 \mathrm{~kg} / \mathrm{ha}$ of Parker's Super Soilife 10-10-10 (Pursell Industries, Sylacauga, AL) $(3.92 \%$ ammonium nitrate, $6.68 \%$ urea nitrogen [1.7\% slow release]) Tween 80 was applied as a mist (Sprā Tool,

and again conventionally cultivated. Rows of Renville and Ben (2.1 m long) were planted by hand with $0.3 \mathrm{~m}$ between rows. Rows of a cultivar planting were separated from rows of the other cultivar by $0.3 \mathrm{~m}$ walkways. Rows of each cultivar were assigned to treatments using a randomized complete block design with five replicate rows per treatment. A border row of Ben and Renville surrounded the experiment site and was not treated. About 2 weeks before the anticipated flowering date, yellow dent corn kernels colonized by $G$. zeae Z-3639 were applied uniformly by hand to the site at approximately 25 kernels per $\mathrm{m}^{2}$. Perithecia appeared on the kernels after about 1 week and were releasing ascospores at the time of anthesis.

Biomass of antagonists AS 43.3, AS 43.4, $\mathrm{OH} 71.4$, and $\mathrm{OH} 182.9$ were produced in SDCL (C:N 6.5) as described above. Prior to application to flowering wheat heads, culture broths were diluted to $25 \%$ of fully colonized, 48 -h liquid culture using $\mathrm{PO}_{4}$ buffer. Tween 80 was added to microbial solutions to a final concentration of $0.036 \%$. Final CFU/ml counts for antagonist treatments were approximately $5 \times$ $10^{8} \mathrm{CFU} / \mathrm{ml}$ and $3 \times 10^{7} \mathrm{CFU} / \mathrm{ml}$ for bacteria and yeast strains, respectively. Treatment suspensions were applied using a $\mathrm{CO}_{2}$ backpack sprayer charged at 2.8 $\mathrm{kg} / \mathrm{cm}^{2}$ and equipped with two no. 10 ConeJet nozzles (R\&D Sprayers, Opelousas, LA) spaced $30 \mathrm{~cm}$ apart and mounted pointing inward at 45 degrees. Treatment suspensions were charged with $\mathrm{CO}_{2}$ just prior to application. Treatments were applied to near runoff just prior to and continuing after sunset to minimize potential UV degradation of antagonist cells. The primary control treatment consisted of plants treated with a solution of buffer/Tween. A second control consisted

Table 2. Influence of microbial antagonists on Fusarium head blight incited by Gibberella zeae Z3639 on the durum wheat cultivars Renville and Ben in greenhouse assays ${ }^{\mathrm{a}, \mathrm{b}}$

\begin{tabular}{lccc}
\hline Treatment & DS $(\boldsymbol{\%})$ & DI $(\%)$ & 100-kw $(\mathbf{g})$ \\
\hline Renville & & & \\
Buffer + Gz & 50 & 96 & 1.89 \\
Buffer alone & $0^{*}$ & $0^{*}$ & $2.76^{*}$ \\
AS 43.3 & $4^{*}$ & $21^{*}$ & $2.30^{*}$ \\
AS 43.4 & $17^{*}$ & $62^{*}$ & $2.41^{*}$ \\
OH 71.4 & $36^{*}$ & 83 & 1.92 \\
OH 182.9 & $27^{*}$ & $79^{*}$ & $2.10^{*}$ \\
LSD $(0.05)$ & 11 & 15 & 0.14 \\
Ben & & & \\
Buffer + Gz & 46 & 97 & 3.19 \\
Buffer alone & $0^{*}$ & $0^{*}$ & $3.64^{*}$ \\
AS 43.3 & $10^{*}$ & $41^{*}$ & $3.37^{*}$ \\
AS 43.4 & $9^{*}$ & $44^{*}$ & 3.24 \\
OH 71.4 & $26^{*}$ & 87 & $3.00^{*}$ \\
OH 182.9 & 43 & 87 & $2.74^{*}$ \\
LSD & $10.05)$ & 18 & 0.16 \\
\hline
\end{tabular}

$\bar{a}$ The middle floret of a central spikelet of a wheat head was co-inoculated with $10 \mu \mathrm{l}$ of a 48-h antagonist-colonized broth (broth $\mathrm{C}: \mathrm{N}=11.0$ ) diluted to $25 \%$ with $\mathrm{PO}_{4}$ buffer (approximately $3 \times 10^{7}$ and $5 \times 10^{8} \mathrm{CFU} / \mathrm{ml}$ for yeast [OH 71.4 and $\mathrm{OH}$ 182.9] and bacterial [AS 43.3 and AS 43.4] antagonists, respectively) and $G$. zeae conidia $\left(5 \times 10^{5}\right.$ conidia per $\left.\mathrm{ml}\right)$.

${ }^{\mathrm{b}} \mathrm{DS}=$ disease severity, $\mathrm{DI}=$ disease incidence, $100-\mathrm{kw}=100-\mathrm{kernel}$ weight, $\mathrm{Gz}=$ G. zeae Z3639. Within a column of a cultivar, means followed by an asterisk are significantly different from the "Buffer + Gz" control (Fisher's protected LSD, $P \leq 0.05$ ). of untreated plants. Treatment applications were contained to individual rows using two PVC pipe frames covered by plastic that were placed on either side of a row to be treated. The PVC pipe frames were thoroughly rinsed after each treatment application. From the morning after treatment application until midmilk kernel development (Feekes growth stage 11.1, [19]), wheat heads were misted with city water for $5 \mathrm{~min} / \mathrm{h}$ from 6:00 A.M. until 8:00 P.M. using four misting sprinklers (Sherman PTR-111 sprinkler, L.R. Nelsen Corporation, Peoria, IL) spaced evenly across the plot with misting heads set approximately $10 \mathrm{~cm}$ above wheat heads, resulting in a total uniform application of approximately $1.5 \mathrm{~cm}$ of water per day. Field assessments of FHB incidence and severity (36) were made by evaluating 60 heads per replicate (300 heads per treatment) when plants were at late milk development. Wheat heads were harvested by hand and threshed using an Almaco thresher when grain reached full maturity. Grain samples obtained from each replicate row were evaluated for 100-kernel weight, and a 10- to 20-g sample of each replicate was evaluated for DON content using a Veratox 5/5 quantitative DON Test Kit (Neogen Corporation, Lansing, MI) per the manufacturer's instructions for grain with a DON concern level of 0.5 to $5 \mathrm{ppm}$. Disease severity and incidence data were normalized when needed using the arcsine transformation before analysis of variance. Means were separated from the buffer/ Tween control at $P \leq 0.05$ using Fisher's protected LSD test (PC SAS, version 6.12, SAS Institute).

Langdon field trial of antagonists against FHB on two durum cultivars. The field site was a Svea loam that was chisel plowed the fall prior to spring planting of durum wheat cultivars Renville and Ben. Prior to planting, urea at $56.0 \mathrm{~kg} / \mathrm{ha}$ $(46+0+0)$ and $78.4 \mathrm{~kg} / \mathrm{ha}(11+52+0)$ was broadcast on the plot, and the site was conventionally cultivated. An Almaco seeder was used to plant plots of Ben and Renville durum in a randomized complete block design (RCBD) with six replicate plots per treatment. Plots were 1.05 by $1.05 \mathrm{~m}$, had a $0.15-\mathrm{m}$ row spacing, and were separated from adjacent plots by approximately $1.05 \mathrm{~m}$. Border plots were not included in the experiment. Additional nitrogen was broadcast applied at the twoleaf stage in the form of urea at 112.1 $\mathrm{kg} / \mathrm{ha}$. The experiment was conducted as described for Peoria, with the following exceptions. Infection of heads by $G$. zeae was dependent on naturally occurring levels of inoculum and rainfall (three rainfall events for a total of $0.8 \mathrm{~cm}$ of rain from flowering through visual disease assessment at late milk kernel development). Biomass of antagonists AS 43.3, AS 43.4, $\mathrm{OH}$ 71.4, $\mathrm{OH}$ 131.1, $\mathrm{OH}$ 181.1, and $\mathrm{OH}$ 182.9 was produced in SDCL (C:N 6.5) as 
described above and stored for $24 \mathrm{~h}$ on ice prior to application. Field assessments of FHB incidence and severity were made by evaluating 60 heads per replicate (360 heads per treatment). When grain reached full maturity, wheat heads were harvested using a Hege plot combine (Hege Maschinen, Waldenburg, Germany) set on the lowest blower setting to retain lighter weight kernels infected by G. zeae. Loss of storage cooler refrigeration after obtaining 100-kernel weights caused stored grain to become moist and negated obtaining accurate DON content values.

Experiment environment and cultivar influence on relative antagonist performance. Relative performance indices of antagonist efficacy (RPI efficacy $_{\text {) }} \quad(32,33)$ were calculated to determine if individual antagonist efficacy varied relative to the other antagonists when strains were tested in greenhouse versus field environments. The influence of the durum cultivar used in an experiment on relative antagonist efficacy was also evaluated. Relative performance indices allow different types of data to be compared using a standard scale and are dimensionless values that will theoretically range from 0 to 100 , in which $100=$ maximum antagonist efficacy relative to the other antagonist strains tested. Assuming FHB severity ratings are normally distributed, $Z$ (the standard normal variate) will range from -2 to +2 (95\% probability) when $Z=(X-\bar{x}) / s$, where $X$ is a single disease rating value observed for an antagonist strain, and $\bar{x}$ and $s$ are the average and standard deviation, respectively, of all values obtained for all antagonist strains in an experiment (34). $\mathrm{RPI}_{\text {efficacy }}$ then is calculated as: $|(Z-2)| * 25$. For data sets where some $Z$ values fall outside the range -2 to $+2, \mathrm{RPI}_{\text {efficacy }}$ is more accurately calculated as: $(2-Z)^{*} 25$. Disease severity data for antagonists AS 43.3, AS 43.4, OH 71.4, and $\mathrm{OH} 182.9$ from the two field trials and the portion of the greenhouse trials that utilized antagonist biomass produced in SDCL (6.5) were utilized to calculate $\mathrm{RPI}_{\text {efficacy }}$ values. For each experiment, an $\mathrm{RPI}_{\text {efficacy }}$ value was calculated for each replication of each antagonist treatment. These values were used to calculate an average $\mathrm{RPI}_{\text {efficacy }}$ for each antagonist strain and for ANOVA and mean separation of antagonist $\mathrm{RPI}_{\text {efficacy }}$ averages. $\mathrm{RPI}_{\text {efficacy }}$ values were initially analyzed as a $2 \times 2$ factorial design with two levels of cultivar (Renville versus Ben) and two levels of experiment location (greenhouse versus field). Because location by cultivar interaction was not significant, overall $\mathrm{RPI}_{\text {efficacy }}$ location and cultivar means for each antagonist were reported and separated at $P \leq$ 0.05 and $P \leq 0.10$ using Fisher's protected LSD test.

\section{RESULTS}

Greenhouse bioassay of antagonists against FHB on two durum cultivars.
All four antagonist treatments significantly reduced disease severity compared with the positive control (buffer + G. zeae Z3639), and three of the four reduced disease incidence when tested on cultivar Renville (Table 2). Bacterial antagonist AS 43.3 decreased disease severity by $92 \%$ and disease incidence by $78 \%$. All the antagonists except $\mathrm{OH} 71.4$ increased 100-kernel weight. Three of four antagonists reduced FHB disease severity, and two of four reduced FHB disease incidence on cultivar Ben (Table 2). Only antagonist AS 43.3 increased 100-kernel weight, while strains OH 71.4 (which decreased disease severity) and $\mathrm{OH} 182.9$ decreased 100-kernel weights.

Greenhouse bioassay of antagonists produced in liquid media with differing carbon:nitrogen ratios. On cultivar Renville, all antagonists, regardless of the $\mathrm{C}: \mathrm{N}$ of the liquid culture production medium, reduced FHB severity (Table 3). Antagonists AS 43.3 and AS 43.4 reduced disease incidence regardless of the $\mathrm{C}: \mathrm{N}$ of the liquid culture production medium, and $\mathrm{OH}$ 71.4 reduced incidence when produced in C:N 11 medium. Disease severity was reduced by as much as $78 \%$ by bacterial antagonist AS 43.3. All antagonists increased 100-kernel weight regardless of the production medium $\mathrm{C}: \mathrm{N}$ except for $\mathrm{OH}$ 182.9 when produced in $\mathrm{C}: \mathrm{N} 6.5$ medium. All antagonists produced on either C:N medium decreased disease severity in tests on cultivar Ben except for $\mathrm{OH} 182.9$ (Table 3). Bacterial antagonists AS 43.3 and AS 43.4 reduced disease incidence, while yeasts $\mathrm{OH} 71.4$ and $\mathrm{OH} 182.9$ did not. One hundred kernel weight results were variable, with the yeast antagonists reducing and the bacterial antagonist AS 43.4 increasing 100-kernel weight. No consistent trend was seen between biological control agent performance and the liquid culture medium used to produce the agent. Averaged over both cultivars, antagonists AS 43.3, AS 43.4, $\mathrm{OH} 71.4$, and $\mathrm{OH} 182.9$ reduced disease severity by an average of $71,58,48$, and $25 \%$, respectively, when produced in $\mathrm{C}: \mathrm{N} 6.5$ medium and by 70 , 75,38 , and $26 \%$ when produced in $\mathrm{C}: \mathrm{N}$ 11.0 medium. Significant interaction of $\mathrm{C}: \mathrm{N}$ and antagonist $(P \leq 0.01)$ for the majority of most dependent variables precluded obtaining overall $\mathrm{C}: \mathrm{N}$ and antagonist effects on either cultivar.

Peoria field trial of antagonists against FHB on two durum cultivars. All six antagonists tested reduced disease severity and incidence compared with the buffer control (Table 4) when tested on cultivar Renville. Antagonists $\mathrm{OH} 71.4$ and $\mathrm{OH} 182.9$ were the most effective treatments in reducing disease severity $(57 \%$ reduction) and incidence (45 and $42 \%$ reduction, respectively). All of the antagonists except $\mathrm{OH} 131.1$ increased 100kernel weight compared with the buffer control. Less disease was observed in the

Table 3. Efficacy of four microbial antagonists produced in C:N 6.5 and 11 media on Fusarium head blight on durum cultivars Renville and Ben in greenhouse tests ${ }^{\mathrm{a}, \mathrm{b}}$

\begin{tabular}{|c|c|c|c|}
\hline Treatment & DS (\%) & DI (\%) & 100-kw (g) \\
\hline \multicolumn{4}{|l|}{ Renville } \\
\hline Buffer + Gz & 80 & 100 & 2.26 \\
\hline AS $43.3(6.5)^{\mathrm{c}}$ & $24 *$ & $72 *$ & $2.85^{*}$ \\
\hline AS 43.3 (11.0) & $18 *$ & $69 *$ & $3.20 *$ \\
\hline AS $43.4(6.5)$ & $36^{*}$ & $78^{*}$ & $2.60 *$ \\
\hline AS $43.4(11.0)$ & $33 *$ & $78 *$ & $2.78 *$ \\
\hline OH $71.4(6.5)$ & $45^{*}$ & 84 & $2.80^{*}$ \\
\hline OH $71.4(11.0)$ & $48^{*}$ & $78^{*}$ & $2.77 *$ \\
\hline OH 182.9 (6.5) & $50 *$ & 84 & 2.33 \\
\hline OH $182.9(11.0)$ & $44 *$ & 84 & $2.66^{*}$ \\
\hline $\operatorname{LSD}_{(0.05)}$ & 13 & 17 & 0.10 \\
\hline \multicolumn{4}{|l|}{ Ben } \\
\hline Buffer + Gz & 82 & 100 & 3.28 \\
\hline AS $43.3(6.5)^{\mathrm{c}}$ & $23^{*}$ & $56^{*}$ & 3.35 \\
\hline AS $43.3(11.0)$ & $31 *$ & $78 *$ & $3.47 *$ \\
\hline AS 43.4 (6.5) & $32 *$ & $78^{*}$ & $3.47 *$ \\
\hline AS $43.4(11.0)$ & $8^{*}$ & $50 *$ & $3.63^{*}$ \\
\hline OH 71.4 (6.5) & $40 *$ & 88 & $3.11 *$ \\
\hline OH $71.4(11.0)$ & $52 *$ & 94 & $2.70^{*}$ \\
\hline OH $182.9(6.5)$ & 71 & 97 & $2.61 *$ \\
\hline OH 182.9 (11.0) & 76 & 94 & $2.70^{*}$ \\
\hline $\operatorname{LSD}_{(0.05)}$ & 14 & 16 & 0.12 \\
\hline
\end{tabular}

a At the onset of flowering, wheat heads were first mist inoculated with an aqueous suspension containing $25 \%$ of a 48 -h antagonist-colonized broth (approximately $3 \times 10^{7}$ and $5 \times 10^{8} \mathrm{CFU} / \mathrm{ml}$ for yeast [OH 71.4 and $\mathrm{OH} 182.9$ ] and bacterial [AS 43.3 and AS 43.4] antagonists, respectively) and $0.036 \%$ Tween 80 , and immediately thereafter with a suspension containing $5 \times 10^{5}$ conidia per $\mathrm{ml}$ of Gibberella zeae isolate Z3639 and $0.036 \%$ Tween 80 . Heads sprayed only with conidia of $G$. zeae in $0.036 \%$ Tween 80 served as controls.

${ }^{\mathrm{b}} \mathrm{DS}=$ disease severity, DI = disease incidence, $100-\mathrm{kw}=100-\mathrm{kernel}$ weight, $\mathrm{Gz}=$ G. zeae Z3639. Within a column of a cultivar, means followed by an asterisk are significantly different from the "Buffer + Gz" control (Fisher's protected LSD, $P \leq 0.05$ ).

${ }^{c}$ Value in parentheses indicates the carbon:nitrogen ratio of the medium used to produce biomass of the antagonist. 
untreated control than in the buffer-treated control (Table 4). Only one of six antagonists was effective in reducing disease severity on cultivar Ben (Table 4). Yeasts
$\mathrm{OH}$ 71.4, $\mathrm{OH} 181.1$, and $\mathrm{OH} 182.9$ reduced disease incidence, while the three bacterial antagonists did not. Antagonists AS 43.3, $\mathrm{OH} 71.4$, and $\mathrm{OH} 182.9$ signifi-

Table 4. Influence of antagonists on the development of Fusarium head blight on durum wheat cultivars Renville and Ben in a 2000 field trial in Peoria, $\mathrm{IL}^{\mathrm{a}, \mathrm{b}}$

\begin{tabular}{lccc}
\hline Treatment & DS $(\boldsymbol{\%})$ & DI $(\%)$ & 100-kw $(\mathbf{g})$ \\
\hline Renville & & & \\
Untreated (Gibberella zeae) & $10^{*}$ & $46^{*}$ & $3.04^{*}$ \\
Buffer (G. zeae) & 14 & 62 & 2.57 \\
AS 43.3 & $8^{*}$ & $43^{*}$ & $2.84^{*}$ \\
AS 43.4 & $9^{*}$ & $45^{*}$ & $2.86^{*}$ \\
OH 71.4 & $6^{*}$ & $34^{*}$ & $2.70^{*}$ \\
OH 131.1 & $9^{*}$ & $44^{*}$ & 2.52 \\
OH 181.1 & $9^{*}$ & $46^{*}$ & $2.71^{*}$ \\
OH 182.9 & $6^{*}$ & $36^{*}$ & $2.87^{*}$ \\
LSD $(0.05)$ & 2 & 8 & 0.11 \\
Ben & & & \\
Untreated (G. zeae) & $8^{*}$ & $43^{*}$ & $3.05^{*}$ \\
Buffer (G. zeae) & 10 & 55 & 2.87 \\
AS 43.3 & 10 & 53 & $3.20^{*}$ \\
AS 43.4 & 9 & 50 & 2.97 \\
OH 71.4 & $7^{*}$ & $37^{*}$ & $3.05^{*}$ \\
OH 131.1 & 49 & 2.86 \\
OH 181.1 & 10 & $46^{*}$ & 2.77 \\
OH 182.9 & 8 & $43^{*}$ & $3.13^{*}$ \\
LSD & $8.05)$ & 8 & 0.12 \\
\hline
\end{tabular}

a Wheat heads were sprayed to near runoff at the time of flowering with a suspension of 48 -h-old antagonist-colonized broth (broth $\mathrm{C}: \mathrm{N}=6.5$ ) diluted to $25 \%$ with weak $\mathrm{PO}_{4}$ buffer and Tween 80 wetting agent (final concentration of $0.036 \%$ ). Microbial suspensions contained approximately $3 \times$ $10^{7}$ and $5 \times 10^{8} \mathrm{CFU} / \mathrm{ml}$ for yeast $(\mathrm{OH} 71.4, \mathrm{OH} 181.1$, and $\mathrm{OH} 182.9)$ and bacterial (AS 43.3, AS 43.4, and $\mathrm{OH} 131.1)$ antagonists, respectively. The "Buffer (G. zeae)" treatment was sprayed to runoff with weak buffer and Tween 80 . All treatments were subjected to infection by ascospore inoculum from natural sources and G. zeae Z3639-colonized yellow dent corn (applied at 25 kernels per $\mathrm{m}^{2} 2$ weeks prior to durum wheat flowering).

${ }^{\mathrm{b}} \mathrm{DS}=$ disease severity, DI = disease incidence, 100-kw $=100-\mathrm{kernel}$ weight. Within a column of a cultivar, means followed by an asterisk are significantly different from the buffer control (Fisher's protected LSD, $P \leq 0.05$ ).

Table 5. Influence of antagonists on the development of Fusarium head blight on durum wheat cultivars Renville and Ben in a 2000 field trial in Langdon, $\mathrm{ND}^{\mathrm{a}, \mathrm{b}}$

\begin{tabular}{lccc}
\hline Treatment & DS $(\%)$ & DI $(\%)$ & 100-kw $(\mathbf{g})$ \\
\hline Renville & & & \\
Untreated (Gibberella zeae) & 5.3 & $14^{*}$ & 3.77 \\
Buffer (G. zeae) & 5.9 & 19 & 3.74 \\
AS 43.3 & 4.6 & 15 & $3.65^{*}$ \\
AS 43.4 & 4.8 & 16 & $3.57^{*}$ \\
OH 71.4 & 4.8 & $12^{*}$ & 3.71 \\
OH 131.1 & $3.0^{*}$ & $11^{*}$ & $3.59^{*}$ \\
OH 181.1 & $2.4^{*}$ & $11^{*}$ & 3.7 \\
OH 182.9 & 6.7 & 18 & $3.65^{*}$ \\
LSD $(0.05)$ & 2.2 & 5 & 0.07 \\
Ben & & & \\
Untreated (G. zeae) & 3.5 & 15 & 4.32 \\
Buffer (G. zeae) & 4.7 & 14 & 4.34 \\
AS 43.3 & 3.5 & 13 & 4.28 \\
AS 43.4 & $2.8^{*}$ & 12 & $4.23^{*}$ \\
OH 71.4 & 3.4 & 11 & $3.97^{*}$ \\
OH 131.1 & 3.4 & 11 & $4.22^{*}$ \\
OH 181.1 & $2.3^{*}$ & $8^{*}$ & 4.27 \\
OH 182.9 & 3.7 & 4.6 & 0.07 \\
LSD $(0.05)$ & 1.8 & & \\
\hline
\end{tabular}

a Wheat heads were sprayed to near runoff at the time of flowering with a suspension of 48 -h-old antagonist-colonized broth (broth $\mathrm{C}: \mathrm{N}=6.5$ ) diluted to $25 \%$ with weak $\mathrm{PO}_{4}$ buffer and Tween 80 wetting agent (final concentration of $0.036 \%$ ). Microbial suspensions contained approximately $3 \times$ $10^{7}$ and $5 \times 10^{8} \mathrm{CFU} / \mathrm{ml}$ for yeast $(\mathrm{OH} 71.4, \mathrm{OH} 181.1$, and $\mathrm{OH} 182.9)$ and bacterial (AS 43.3, AS 43.4, and $\mathrm{OH} 131.1)$ antagonists, respectively. The "Buffer (G. zeae)" treatment was sprayed to runoff with weak $\mathrm{PO}_{4}$ buffer and Tween 80 . All treatments were subjected to infection by ascospore inoculum from natural sources.

${ }^{\mathrm{b}} \mathrm{DS}=$ disease severity, DI $=$ disease incidence, and 100-kw $=100$-kernel weight. Within a column of a cultivar, means followed by an asterisk are significantly different from the buffer control (Fisher's protected LSD, $P \leq 0.05$ ).

cantly increased 100-kernel weight (Table 4). The DON content of the harvested grain did not significantly differ from the controls for any of the treatments on either cultivar. On cultivar Renville, the DON values for treatments Untreated, Buffer, and antagonists AS 43.3, AS 43.4, OH 71.4, $\mathrm{OH} 131.1, \mathrm{OH} 181.1$, and $\mathrm{OH} 182.9$ were $12.8,16.8,16.6,15.0,16.8,13.8$, 14.8, and 15.6, respectively, with an $\operatorname{LSD}_{(0.05)}$ of 6.3. On cultivar Ben, DON values were $13.8,13.8,15.4,14.6,15.0$, $15.5,16.5$, and 14.8 , respectively, with an $\operatorname{LSD}_{(0.05)}$ of 8.1 .

Langdon field trial of antagonists against FHB on two durum cultivars. Antagonists $\mathrm{OH} 131.1$ and $\mathrm{OH} 181.1$ reduced disease severity on cultivar Renville (Table 5), while antagonists AS 43.4 and OH 181.1 reduced disease severity on cultivar Ben (Table 5). Three of the six antagonists reduced disease incidence on cultivar Renville, while only $\mathrm{OH} 181.1$ reduced disease incidence on cultivar Ben. Unlike the Peoria results, 100-kernel weight was decreased by four and three antagonists on cultivars Renville and Ben, respectively (Table 5).

Experiment environment and cultivar influence on relative antagonist performance. Bacterial antagonist AS 43.3 had a significantly greater RPI efficacy $_{\text {in the }}$ greenhouse environment than in the field $(P \leq 0.10$, Table 6$)$. The other bacterial antagonist, AS 43.4, also had a greater, although not statistically significant, $\mathrm{RPI}_{\mathrm{ef}}$ ficacy value in greenhouse tests than in field tests. Yeast $\mathrm{OH} 182.9$ had a significantly greater $\mathrm{RPI}_{\text {efficacy }}$ value when tested in the field environment $(P \leq 0.05$, Table 6$)$. The other yeast antagonist, $\mathrm{OH} 71.4$, also had a greater, although not statistically significant, $\mathrm{RPI}_{\text {efficacy }}$ value in field tests than in greenhouse tests. There were no RPI differences for any antagonist when comparing the RPI $I_{\text {efficacy }}$ of each antagonist on the two durum cultivars tested (data not shown), indicating that, relative to each other, the antagonists performed very similarly in reducing disease severity regardless of the durum cultivar used in the experiment.

\section{DISCUSSION}

The results presented represent the first demonstration of the feasibility of biologically controlling FHB on durum wheats. Antagonist B. subtilis AS 43.3 reduced disease severity and incidence by as much as 96 and $78 \%$, respectively, in greenhouse studies (Table 2), while antagonist Cryptococcus sp. $\mathrm{OH} 181.1$ reduced disease severity and incidence by as much as 59 and $42 \%$, respectively, in field studies (Table 5) compared with the buffer control. Interestingly, bacterial antagonists $B$. subtilis AS 43.3 and AS 43.4 tended to be more successful in reducing disease in the greenhouse environment than were the yeast antagonists regardless of the durum culti- 
var used in the bioassay (Tables 2 to 6). Conversely, the yeast antagonists Cryptococcus sp. $\mathrm{OH} 71.4$ and $C$. nodaensis $\mathrm{OH}$ 182.9 were more successful than the bacterial antagonists on both cultivars when tested in the field (Tables 2 to 6). RPI efficacy $_{\text {ict }}$ values were higher for the two bacterial strains in greenhouse tests than in field tests, while the converse was true for the yeast strains (Table 6), demonstrating that the relative efficacy of the bacteria deteriorated while that of the yeasts improved when comparing greenhouse results with field results. This is in contrast to the results of Perondi et al. (26), who found yeast and bacterial reduction of FHB severity in greenhouse and field environments to be similar in most cases. The trends observed in the current research could be partially due to the influence of rain in the field but not in the greenhouse environment. The bacterial strains AS 43.3 and AS 43.4 produce bioactive compounds in liquid culture that are active in suppressing FHB severity in greenhouse bioassays (30). These compounds would be retained on heads in greenhouse bioassays but could be susceptible to wash-off during rain events or supplemental mist irrigation in the field. Although no difference in the relative performance of the antagonists was found when comparing results on the two durum cultivars, host variety can influence the efficacy of individual antagonists (18) and the relative efficacy of antagonists in the control of Fusarium disease (32). Tests on additional cultivars of durum and other wheats should be conducted before final conclusions on the influence of cultivar on relative antagonist performance are reached.

In both greenhouse and field results, the influence of antagonists on 100-kernel weight was highly variable, with at least one antagonist treatment either increasing (Tables 2 to 4) or decreasing (Tables 2, 3, and 5) these values. We have not seen any

Table 6. Comparison of efficacy relative performance indices $\left(\mathrm{RPI}_{\text {efficacy }}\right)$ for four antagonists when tested in greenhouse versus field environments on flowering wheat heads ${ }^{\mathrm{a}}$

\begin{tabular}{lcl}
\hline & \multicolumn{2}{c}{ RPI $_{\text {efficacy }} \mathbf{b}$} \\
\cline { 2 - 3 } Treatment & Greenhouse & Field \\
\hline AS 43.3 & $64.2^{*}$ & $48.0^{*}$ \\
AS 43.4 & 55.8 & 49.6 \\
OH 71.4 & 47.7 & 53.9 \\
OH 182.9 & $32.2^{* *}$ & $48.6^{* *}$ \\
\hline
\end{tabular}

a Durum cultivars Ben and Renville were used in greenhouse and field bioassays. Antagonists were produced in C:N 6.5 liquid medium.

${ }^{b} \mathrm{RPI}_{\text {efficacy }}$ values were calculated using disease severity data from repeated greenhouse and field experiments, each with four or more replicates per treatment.

c Within a row, means followed by single or double asterisks are significantly different at $P \leq 0.10$ and $P \leq 0.05$, respectively (Fisher's protected LSD). effect, in multiple studies, of any antagonist on wheat development when used to inoculate wheat heads in the absence of the pathogen (N. I. Khan, unpublished). At least for the greenhouse results, it is possible that some experiments were harvested before all heads in all treatments reached grain maturity, resulting in the control treatment having completed grain fill while prematurely terminating grain fill for some treatments showing partial control of FHB. The reason for sporadic instances of reduced 100-kernel weight in durum wheat treated in field trials by the same antagonists that increase 100-kernel weight in other trials is not readily apparent. The 100-kernel weight parameter for fieldgrown wheat measures not only the influence of FHB but other biotic and abiotic factors, which further complicates interpreting the biological significance, if any, of the occasional yield reduction observed in the current study.

The C:N ratio of the medium used to produce antagonists for greenhouse trials had little effect on the efficacy of the antagonist strains in greenhouse studies. Because the liquid culture production environment can influence biological control agent performance in other pathosystems $(28,29,32,33)$ and FHB antagonists showed markedly different relative efficacy when tested in field versus greenhouse environments (Table 6), the role of the nutritional environment of the liquid culture production medium should not be considered inconsequential in this pathosystem before additional production media have been utilized and the biomass tested in field environments.

The application of biological control agents in the field is inherently more variable and challenging than in the greenhouse. Factors of consequence to the successful application of FHB antagonists in the field include the deleterious effects of ultraviolet light (39), variable and sporadic arrival of pathogen inoculum on wheat heads over an extended period of head susceptibility $(8,10)$, and a phylloplane environment that fluctuates widely in temperature, moisture, and available nutrients. Despite these potential constraints, results of these studies indicate that biological control could currently contribute to the reduction of FHB in the field, especially given the lack of acceptable control measures available. Further research on optimizing fermentation, processing, and formulation $(13,39,43)$ protocols for these antagonists coupled with investigation of their ecology and mode of action in situ should increase the role that biological control could play in reducing the impact of FHB on wheat production.

\section{ACKNOWLEDGMENTS}

This study was made possible, in part, by funding provided by the Dakota Growers Pasta Company, Carrington, ND. Additional funding was provided by the U.S. Wheat and Barley Scab Initiative. Pat Hart provided expert analysis of DON content of grain samples. Masterful technical assistance was provided by Jennifer Sloan. We thank C. P. Kurtzman and his collaborators C. J. Robnett, L. Tjarks, J. W. Fell, and T. Boekhout for their expertise in identifying the yeast isolates. The help of John Lukach, Marcia McMullen, and Michele Giovannini in establishing and maintaining field plots is appreciated.

\section{LITERATURE CITED}

1. Bai, G.-H., and Shaner, G. 1994. Scab of wheat: Prospects for control. Plant Dis. 78:760-766.

2. Bai, G.-H., Shaner, G., and Ohhm, H. 2000. Inheritance of resistance to Fusarium graminearum in wheat. Theor. Appl. Genet. 100:1-8.

3. Bozzini, A. 1988. Origin, distribution, and production of durum wheat in the world. Pages 1-16 in: Durum Wheat: Chemistry and Technology. G. Fabriani and C. Lintas, eds. American Association of Cereal Chemists, St Paul, MN.

4. Bujold, I., Paulitz, T. C., and Carisse, O. 2001. Effect of Microsphaeropsis sp. on the production of perithecia and ascospores of Gibberella zeae. Plant Dis. 85:977-984.

5. Bushnell, W. R., Somers, D. A., Giroux, R. W., Szabo, L. J., and Zeyen, R. J. 1998. Genetic engineering of disease resistance in cereals. Can. J. Plant Pathol. 20:137-149.

6. Dexter, J. E., Marchylo, B. A., Clear, R. M., and Clarke, J. M. 1997. Effect of Fusarium head blight on semolina milling and pastamaking quality of durum wheat. Cereal Chem. 74:519-525.

7. Dill-Macky, R., and Jones, R. K. 2000. The effect of previous crop residues and tillage on Fusarium head blight of wheat. Plant Dis. 84:71-76.

8. Fernando, W. G. D., Miller, J. D., Seaman, W. L., Seifert, K., and Paulitz, T. C. 2000. Daily and seasonal dynamics of airborne spores of Fusarium graminearum and other Fusarium species sampled over wheat plots. Can. J. Bot. 78:497-505.

9. Forsyth, O. M., Yoshizawa, T., Morooka, N., and Tuite, J. 1977. Emetic and refusal activity of deoxynivalenol to swine. Appl. Environ. Microbiol. 34:547-552.

10. Francl, L., Shaner, G., Bergstrom, G., Gilbert, J., Pedersen, W., Dill-Macky, R., Sweets, L. Corwin, B., Jin, Y., Gallenberg, D., and Wiersma, J. 1999. Daily inoculum levels of Gibberella zeae on wheat spikes. Plant Dis. 83:662-666.

11. Fuming, D., Shiming, Z., Beiqi, Z., and An, Z 1994. Control effects of four bacterial strains on wheat scab (Fusarium graminearum). Acta Agric. Shanghai 10:59-63.

12. González, H. H. L., Martínez, E. J., Pacin, A., and Resnik, S. L. 1999. Relationship between Fusarium graminearum and Alternaria alternata contamination and deoxynivalenol occurrence on Argentinian durum wheat. Mycopathologica 144:97-102.

13. Guetsky, R., Shtienberg, D., Elad, Y., and Dinoor, A. 2001. Combining biocontrol agents to reduce the variability of biological control. Phytopathology 91:621-627.

14. Hesseltine, C. W., Rogers, R. F., and Shotwell, O. 1978. Fungi, especially Gibberella zeae, and zearalenone occurrence in wheat. Mycologia 70:14-18.

15. Jones, C. R., and Samac, D. A. 1996. Biological control of fungi causing alfalfa seedling damping-off with a disease-suppressive strain of Streptomyces. Biol. Control 7:196-204.

16. Jones, R. K. 2000. Assessments of Fusarium head blight of wheat and barley in response to fungicide treatment. Plant Dis. 84:1021-1030. 
17. Khan, N. I., Schisler, D. A., Boehm, M. J., Slininger, P. J., and Bothast, R. J. 2001. Selection and evaluation of microorganisms for biocontrol of Fusarium head blight of wheat incited by Gibberella zeae. Plant Dis. 85:1253-1258.

18. King, E. B., and Parke, J. L. 1993. Biocontrol of Aphanomyces root rot and Pythium damping-off by Pseudomonas cepacia AMMD on four pea cultivars. Plant Dis. 77:1185-1188.

19. Large, E. C. 1954. Growth stages in cereals. Illustrations of the Feekes scale. Plant Pathol. 3:128-129.

20. Lewis, J. A., Papavizas, G. C., and Hollenbeck, M. D. 1993. Biological control of damping-off of snapbeans caused by Sclerotium rolfsii in the greenhouse and field with formulations of Gliocladium virens. Biol. Control 3:109-115

21. Matthies, A., and Buchenauer, H. 2000. Effect of tebuconazole (Folicur®) and prochloraz (Sportak®) treatments on Fusarium head scab development, yield and deoxynivalenol (DON) content in grains of wheat following artificial inoculation with Fusarium culmorum. J. Plant Dis. Prot. 107:33-52.

22. McCallum, B. D., Tekauz, A., and Gilbert, J. 2001. Vegetative compatibility among Fusarium graminearum (Gibberella zeae) isolates from barley spikes in southern Manitoba. Can. J. Plant Pathol. 23:83-87.

23. McMullen, M., Jones, R., and Gallenberg, D. 1997. Scab of wheat and barley: A reemerging disease of devastating impact. Plant Dis. 81:1340-1348.

24. Miller, J. D., Culley, J., Fraser, K., Hubbard, S., Meloche, F., Ouellet, T., Seaman, W. L., Seifert, K. A., Turkington, K., and Voldeng, H. 1998. Effect of tillage practice on Fusarium head blight of wheat. Can. J. Plant Pathol. 20:95-103.

25. O'Donnell, K., Corby Kistler, H., Tacke, B. K., and Casper, H. H. 2000. Gene genealogies reveal global phylogeographic structure and reproductive isolation among lineages of Fusarium graminearum, the fungus causing wheat scab. Proc. Nat. Acad. Sci. 97:79057910.

26. Perondi, N. L., da Luz, W. C., and Thomas, R. 1996. Controle microbiológico da giberela do trigo. Fitopatol. Bras. 21:243-249.

27. Sato, I., Kobayasi, H., Hanya, Y., Abe, K., Murakami, S., Scorzetti, G., and Fell, J. W.
1999. Cryptococcus nodaensis sp. nov., a yeast isolated from soil in Japan that produces salt-tolerant and thermostable glutaminase. J. Industr. Microbiol. Biotechnol. 22:127-132.

28. Schisler, D. A., Burkhead, K. D., Slininger, P. J., and Bothast, R. J. 1998. Selection, characterization and use of microbial antagonists for the control of Fusarium dry rot of potatoes. Pages 199-222 in: Plant-Microbe Interactions and Biological Control. G. J. Boland and L. D. Kuykendall, eds. Marcel Dekker, Inc., New York.

29. Schisler, D. A., Jackson, M. A., and Bothast, R. J. 1991. Influence of nutrition during conidiation of Colletotrichum truncatum on conidial germination and efficacy in inciting disease in Sesbania exaltata. Phytopathology 81:587-590.

30. Schisler, D. A., Khan, N. I., and Boehm, M. J. 2002. Biological control of Fusarium head blight of wheat and deoxynivalenol levels in grain via use of microbial antagonists. Pages 53-69 in: Mycotoxins and Food Safety. J. W. DeVries, M. W. Trucksess, and L. S. Jackson, eds. Kluwer Academic/Plenum Publishers, New York.

31. Schisler, D. A., and Slininger, P. J. 1994. Selection and performance of bacterial strains for biologically controlling Fusarium dry rot of potatoes incited by Gibberella pulicaris. Plant Dis. 78:251-255.

32. Schisler, D. A., Slininger, P. J., Hanson, L. E., and Loria, R. 2000. Potato cultivar, pathogen isolate, and antagonist cultivation medium influence the efficacy and ranking of bacterial antagonists of Fusarium dry rot. Biocontrol Sci. Technol. 10:267-279.

33. Slininger, P. J., Schisler, D. A., and Bothast, R. J. 1994. Two-dimensional liquid culture focusing: A method of selecting commercially promising microbial isolates with demonstrated biological control capability. Pages 29-32 in: Improving Plant Productivity with Rhizosphere Bacteria. M. H. Ryder, P. M. Stephens, and G. D. Bowen, eds. 3rd Int. Workshop Plant Growth-Promoting Rhizobacteria, Adelaide, S. Australia. Graphic Services, Adelaide, Australia. CSIRO Division of Soils: Glen Osmond.

34. Snedecor, G. W., and Cochran, W. G. 1980. Statistical Methods. 7th ed. Iowa State University, Ames.

35. Snijders, C. H. A. 1990. Fusarium head blight and mycotoxin contamination of wheat, a review. Neth. J. Plant Pathol. 96:187-198.

36. Stack, R. W., and McMullen, M. P. 1995. A visual scale to estimate severity of Fusarium head blight in wheat. N.D. State Univ. Ext. Serv. Bull. PP-1095.

37. Stockwell, C. M., da Luz, W. C., and Bergstrom, G. C. 1997. Biocontrol of wheat scab with microbial antagonists. (Abstr.) Phytopathology 87:S94.

38. Suty, A., and Mauler-Machnik, A. 1997 Fusarium ear blight on wheat-epidemiology and control of Gibberella zeae, the teleomorph of Fusarium graminearum, with Folicur®. Pages 243-246 in: Diagnosis and Identification of Plant Pathogens. Proc. Int Sympos. Eur. Foundation Plant Pathol., 4th. H.-W. Dehne, G. Adam, M. Diekmann, J. Frahm, A. Mauler-Machnik, and P. Van Halteren, eds. Kluwer Academic Publishers, Dordrecht, Germany.

39. Tamez-Guerra, P., McGuire, M. R., Behle, R. W. Shasha, B. S., and Galán Wong, L. J. 2000. Assessment of microencapsulated formulations for improved residual activity of Bacillus thuringiensis. J. Econ. Entomol. 93:219-225.

40. Vesonder, R. F., and Hesseltine, C. W. 1980. Vomitoxin: Natural occurrence on cereal grains and significance as a refusal and emetic factor to swine. Process Biochem. 16:12-15.

41. Walker, S. L., Leath, S., Hagler, W. M., Jr., and Murphy, J. P. 2001. Variation among isolates of Fusarium graminearum associated with Fusarium head blight in North Carolina. Plant Dis. 85:404-410.

42. Wang, Y.-P., Liu, Y.-Q., Pan, N.-S., and Chen, Z.-L. 1992. Preliminary studies of the control of wheat scab with Bacillus subtilis A014 strain. Chinese J. Biol. Control 8:54-57.

43. Wraight, S. P., Jackson, M. A., and de Kock, S. L. 2001. Production, stabilization and formulation of fungal biocontrol agents. Pages 253-287 in: Fungi as Biocontrol Agents: Progress Problems and Potential. T. M. Butt, C. Jackson, and N. Magan, eds. CAB International, Wallingford, England.

44. Yi, C., Kaul, H.-P., Kubler, E., Schwadorf, K. and Aufhammer, W. 2001. Head blight (Fusarium graminearum) and deoxynivalenol concentration in winter wheat as affected by precrop, soil tillage and nitrogen fertilization. J. Plant Dis. Prot. 108:217-230. 